\title{
The Development Of Technical Education In Pakistan
}

\author{
Hafiz Muhammad Inamullah, IER, Kohat University, Pakistan \\ M. Naseeruddin, IER, Kohat University, Pakistan \\ Ishtiaq Hussain, IER, Kohat University, Pakistan \\ S. Iftikhar Shah, Director (TEVTA) Punjab, Pakistan
}

\begin{abstract}
The main objectives of this study were to highlight the present profile of technical education in NWFP, Pakistan, to pinpoint the physical facilities problems of technical education, to highlight the academic problems in technical education, and to recommend strategies for the improvement of technical education in Pakistan.
\end{abstract}

\section{INTRODUCTION}

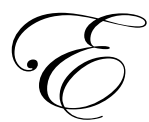

ducation is the fundamental indicator of the national development. Education develops the human resources, which is the most important factor of national development. A study by Curle (1966) indicates that there was a close relationship between a country's attitude toward the education of its people and the rate of its development. Another study conducted by the same author concludes that countries investing more in education had a higher rate of economic growth as compared to the countries spending less on education. It has been emphasized that work-oriented education should be recognized as an effective means for fulfillment of individual needs and for employment (Gordon, 1971).

Technical education, by its nature, has to be relevant to other sectors of society in order to educate and train the technical personnel and skilled workers needed for socio-economic development. Nowadays, society is rapidly changing; it is essential for technical education to strengthen its linkage with the world of work in order to meet changing requirements. To cope with this changing nature of the workplace, it is essential to develop through lifelong education, the necessary skills required to perform a job.

"Sustained socio economic development is not possible by mere capital investment, unless it is reinforced with proper supply of adequately trained scientific and technical manpower. Rapid economic growth demands a mixture of skilled workers, tradesmen, technicians, technologists, engineers, researchers and development scientists trained in the areas linked with national development requirements and needs of the industry" (Govt. of Pakistan, 1998).

The urgency of scientific and technical education was explicitly emphasized by the founder of the nation, Quaid-e-Azam Muhammad Ali Jinnah, to the participants of First National Education Conference (Govt. of Pakistan, 1947). The education policy of Government of Pakistan (1972-1980) has stressed a massive shift from general education to more purposeful Agro-technical education. The National Educational Policy (1978) has also given great importance to technical education by putting it as one of the major goals of education. The report of the technical education committee (Govt. of Pakistan, 1953) also provided a comprehensive plan to develop technical education.

\section{Population And Sampling}

The target population of all teachers and students in 22 government polytechnic institutes and government colleges of technology constituted the population of the study in 2007. The 2004 Technical Education Directory of NWFP was used to identify the population, which served as the sampling frame for the study. Using the formula recommended by Krejcie and Morgan (1970), a sample of 150 teachers and 300 students was needed for the study. 
A random sampling technique was used to select teachers and students from the 32 technical colleges in the NWFP of Pakistan. Fifteen technical colleges were randomly selected to participate in the study in order to achieve the desired sample size (15 colleges with an average of 10 teachers and 20 students per college). According to Gay (1996), cluster sampling is more convenient when the population is very large or spread out over a wide geographic area. Sometimes it is the only feasible method of selecting a sample.

\section{Instrumentation}

A five-part questionnaire was designed by the investigator for use in measuring selected variables. The questionnaire for teachers and students of government polytechnic institutes and government colleges of technology consisted of 59 items of personal data. Item numbers 1 and 2 were related to the clarity of objectives of technical education; item numbers 3 through13 were related to the availability of physical facilities; and item numbers 14 through 34 were related to the academic facilities. Eight items were related to the curriculum and two were openended. All of the items were on five-point scale.

\section{Data Collection}

The Total Design Method (TDM) of conducting surveys (Dillman, 1978) was followed in all stages of the questionnaire construction and implementation process. A packet containing a letter, instructions for administering the questionnaire, and copies of the questionnaire were mailed to the principal of each college selected for the study. As per the schedule, a total of 15 questionnaires were sent to principals in October 2007. Usable questionnaires were returned for a response rate of $72 \%$. Because a number of questionnaires were returned incomplete and there was no way to conduct appropriate follow-up procedures to control non-responses, the results of the study can only be generalized to the 123 teachers and 269 students who provided usable data.

\section{Data Analysis}

Data collected on the above-mentioned five-point scale were analyzed by using Chi Square test at the level of significance of 0.05 . The formula for calculating chi-squire $\left(\chi^{2}\right)$ is stated as follows:

$$
\chi^{2}=\sum \frac{(\text { fo }- \text { fe })^{2}}{\text { fe }}
$$

Where

fo $\quad=$ frequency of observed or experimentally determined facts

fe $\quad=$ expected frequency of occurrence on hypothesis (Garrett, 1997)

There were two open-ended questions in each questionnaire. In one of the questions, the respondents were asked to enlist the problem related to technical education, while in the other question, they were asked to offer their suggestions for the improvement of technical education.

\section{CONCLUSION}

The objectives of the study were to explore the perception of teachers and students regarding the physical and academic facilities of technical education in NWFP of Pakistan. The results show that the facilities of laboratory and computer are sufficient, while building, transport, first aid, hostel, fire fighting facilities, latest reading material, on line research facilities, and budget, are not sufficient in the institutions of technical education. It is revealed that the overall physical facilities were not satisfactory. Similarly, the teachers were academically sound but not abreast with modern teaching techniques, nor is a budget allocated for their training. There were no guidance and counseling services in the system. 
Technical is not helpful in employment, nor is improvement made by periodical evaluations. The curriculum is outdated, theory-oriented and stereotype. The examination system is only theory oriented and does not evaluate the competency of students in technical know-how. There is no link between industry and technical education. There is no well-defined quality management, reward/award and legislation for industry to have a proper linkage system. There is limited access and no system at the national level. Shortage of the right people for right jobs in the field of technical education is also a burning problem.There is lack of industrial experience of teachers, skill orientation in curriculum, and opportunity for teachers to get training from developed countries. It was recommended in the National Education policy (1998-2010) to the government of Pakistan (1998). There is no job security for teachers and no close relations with the related industry. The same results have been reported by Ali (1985), Sindh Board of Technical Education (1974) and Shah (2005).

\section{AUTHOR INFORMATION}

Hafiz Muahmmad Inamulla, Ph. D., IER, Kohat University, Pakistan

Ishtiaq Hussain Ph. D., IER, Kohat University, Pakisatn

M. Naseer Ud din Ph. D., IER, Kohat University, Pakistan

S. Iftekhar Shah, Director Technical \& Vocational Education, Punjab, Pakistan

\section{REFERENCES}

1. Ali, M. M. 1985. Themes in Technical Education: Study of some quality improvement aspects. Sindh Board of Technical Education, Karachi. pp. 112-174

2. Adiviso, F. B. 2003. Restructuring of Technical Education and Vocational Training System. ADB TA No.4048-Pak. Final Report. Govt. of Pakistan and Asian Development Bank. p. 196.

3. Ali, M. M. 1986, Development of Technical Education in Sindh. Sindh Board of Technical Education, Karachi. p. 137.

4. $\quad$ Curle. A, 1966. Planning for Education in Pakistan. Taristoch Publications, London. p. 208.

5. Dillman, D. (1978).Mail and telephone surveys: The total design method. New York: John Wiley \& Sons, Inc.

6. Krejcie, R.V. \& Morgan, D.W. (1970). Determining sample size for research. Educational and Psychological Measurements, 30, 607-610.

7. Garrett, H. E. 1997. Statistics in Psychology and Education. Combine Printers, Lahore, p. 253.

8. Gay, L. R. 1996. Educational Research: Competencies for Analysis and Application. Macmillan Publishing Company, New York, USA. pp. 223-231.

9. Gordon, F. Law. 1971. Contemporary Concepts in Vocational Education. D. C. American Vocational Association, Washington, USA. p. 20.

10. Govt. of Pakistan, 1947. Proceedings of the Pakistan Educational Conference. Ministry of Interior, Education Division, Karachi. pp. 33-35.

11. Govt. of Pakistan. 1948. Proceedings of First Meeting of advisory Board of Education held at Karachi, 7-9June. Manga Publications, Karachi. p. 13.

12. Govt. of Pakistan. 1953. Report of Technical Education Committee, Appointed by Council of technical Education for Pakistan, Education Division. Manga Publications, Karachi. p. 5.

13. Govt. of Pakistan. 1972. The Education Policy, 1972-1980. Ministry of Education, Islamabad. pp. 17-19.

14. Govt. of Pakistan. 1998. National Education Policy, 1998-2010. Ministry of Education, Islamabad. pp. 5563.

15. Govt. of Pakistan. 2001. Education Sector Reforms (ESR) Action Plan. Ministry of Education, Islamabad. p. 35.

16. Shah.I.H.2004. problems and propects of ytechnical education in Pakistan,UIER,UAAR,Rawalpindi. 
NOTES 